\title{
The Effect of Isolation on the Number of Woodland Birds in Small Woods in the Netherlands
}

\author{
P. Opdam; D. van Dorp; D. J. F. Ter Braak \\ Journal of Biogeography, Vol. 11, No. 6. (Nov., 1984), pp. 473-478.
}

Stable URL:

http://links.jstor.org/sici?sici=0305-0270\%28198411\%2911\%3A6\%3C473\%3ATEOIOT\%3E2.0.CO\%3B2-2

Journal of Biogeography is currently published by Blackwell Publishing.

Your use of the JSTOR archive indicates your acceptance of JSTOR's Terms and Conditions of Use, available at http://www.jstor.org/about/terms.html. JSTOR's Terms and Conditions of Use provides, in part, that unless you have obtained prior permission, you may not download an entire issue of a journal or multiple copies of articles, and you may use content in the JSTOR archive only for your personal, non-commercial use.

Please contact the publisher regarding any further use of this work. Publisher contact information may be obtained at http://www.jstor.org/journals/black.html.

Each copy of any part of a JSTOR transmission must contain the same copyright notice that appears on the screen or printed page of such transmission.

The JSTOR Archive is a trusted digital repository providing for long-term preservation and access to leading academic journals and scholarly literature from around the world. The Archive is supported by libraries, scholarly societies, publishers, and foundations. It is an initiative of JSTOR, a not-for-profit organization with a mission to help the scholarly community take advantage of advances in technology. For more information regarding JSTOR, please contact support@jstor.org. 


\title{
The effect of isolation on the number of woodland birds in small woods in the Netherlands
}

\author{
P. OPDAM, D. VAN DORP* and C. J. F. TER BRAAK $\dagger$ Research Institute for Nature Manage- \\ ment, Kasteel Broekhuizen, 3956 ZR Leersum (NL), and †Institute TNO for Mathematics, \\ Information Processing and Statistics, P.O. Box 100, 6700 AC Wageningen, The Netherlands.
}

\begin{abstract}
The effect of isolation of forest habitat islands on the number of breeding woodland birds was studied in thirty-six woodlots, varying in size and differing in degree of isolation. Various isolation variables were calculated. Multiple regression analysis showed that, apart from patch area, the amount of woodland near the forest island and the distance to an extensive forest area have significant effects on the number of woodland birds. This result is not necessarily at variance with the apparent flying abilities of birds.
\end{abstract}

\section{Introduction}

One of the predictions from the MacArthurWilson hypothesis on island biogeography (MacArthur \& Wilson, 1967) for bird communities is that remote islands support fewer species of birds than islands close to a land mass that functions as a species pool. This difference is explained by the barrier effect of the sea diminishing the immigration rate of land birds. Lack (1976) stressed the flying abilities of many birds, concluding that dispe:sal over the sea could not be a critical factor. However, Abbott (1974) and Reed (1981) found that distance to the shore explained a significant part of the variation in the number of land bird species on islands.

The theory of island biogeography has been used frequently to predict processes in terrestrial communities on the mainland (e.g. Diamond, 1975), even before adequate evidence for its validity had been collected (see, for a critical review, Gilbert, 1980). The effect of isolation on the number of bird species in habitat islands was demonstrated by Vuilleumier (1970) and Johnson (1975) in

* Present address: Reigerstraat 65, 7731 ZR Ommen (NL), The Netherlands. remote habitat patches in mountains. Fritz (1979) could demonstrate the effect of isolation on the occurrence of spruce grouse (Canachites canadensis) in patches of spruce forest. Whitcomb et al. (1981) also concluded that isolation affects the number of forest interior birds in small woods. Contrarily Helliwell (1976) found no evidence that either the density of woods in the neighbourhood or the distance to other woodland areas had any effect on the number of breeding birds in British woods.

This paper deals with woodland birds in small woods (mostly less than 50 ha) in the Rhine valley in The Netherlands. Adjacent to this valley are some large forest areas (Fig. 1). Small woods (mostly estates) are scattered in the valley at various distances from these forest 'mainlands', which are regarded as sources of woodland species dispersing into the valley. Of course, birds may also disperse from one woodlot to another or use small woodlots as stepping stones during their movements.

We examine the number of woodland birds species in these woodlots in relation to the degree of isolation. It is necessary to account also for the role of area as the main factor influencing the species number. 


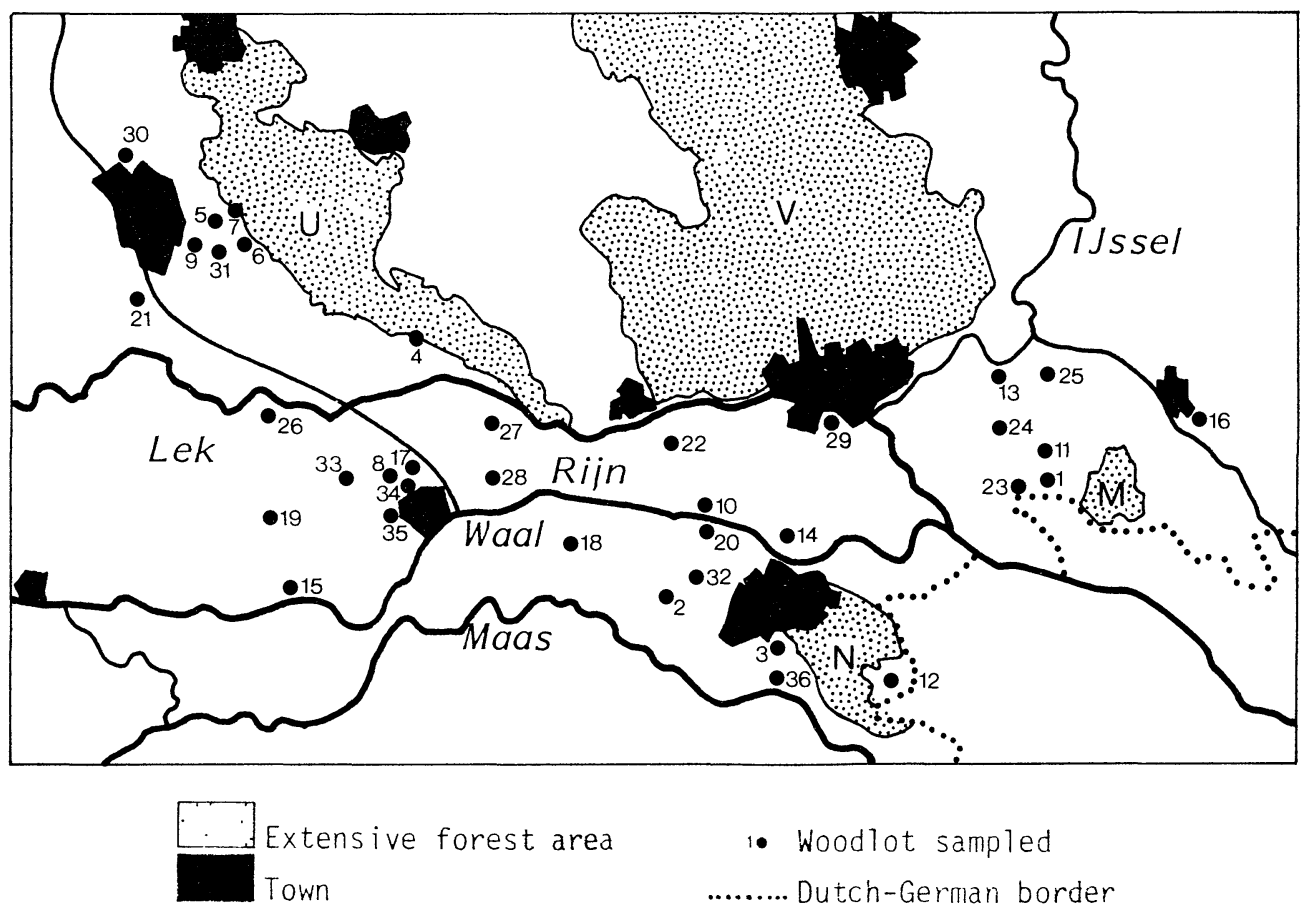

FIG. 1. Distribution of thirty-six patches of mature forest in the Rhine valley in The Netherlands, showing their position relative to extensive forest areas.

\section{Methods}

\section{Bird data}

Breeding bird censuses in thirty-six woods were selected from files of the Vogelwacht Utrecht and the Research Institute for Nature Management (including those of the Vogelwerkgroep Grote Rivieren) and from private diaries and unpublished reports. All censuses have been carried out between 1972 and 1980 . We selected twenty-four species of woodland birds (see Table 3) for which the large forest areas bordering the Rhine valley could be regarded as main areas of distribution. Most selected species inhabit mature woods and their occurrence in the woods is supposed not to be affected by variability in shrub and herb layer. The accuracy of the censuses permits an analysis of presence-absence patterns (Van Dorp, 1982). Variation in sampling methods is thought not to depend on the degree of isolation of woodlots. The variable used in the regression analysis is the number of woodland species $(\mathrm{S})$.

\section{Variables of size and isolation}

The selected sites have been woodland for many years and all are characterized by stands of mature deciduous trees (mainly Quercus robur, Fraxinus excelsior, Fagus sylvatica and Populus sp.). We assume that any site includes patches of habitat for most of the species selected. Measures of vegetation structure were not available. The selection of bird species associated with the tree layer makes quantification of vegetation structure in other layers less crucial. We assume that tree layer diversity is correlated to area size but not to isolation variables.

One variable for overall size and four measures of isolation were calculated:

Area $(A)$ : the total size (in ha) of the wooded area excluding coppice and shrubs, measured from recent air photographs and maps.

Distance to species pool (DS): the shortest distance between the wood and the border of the nearest large forest area (in $\mathrm{km}$ ). 
Distance to nearest wood ( $D N)$ : the shortest distance (in $\mathrm{km}$ ) between a wood and the nearest patch of forest of any type exceeding 25 ha in size.

Area of wood within a radius of $3 \mathrm{~km}$ from the centre of the woodlot (AF3). Seven classes of area were distinguished, and the total amount of wood within $3 \mathrm{~km}$ was estimated according to these categories.

Area of wood within a radius of $5 \mathrm{~km}$ from the centre of the woodlot (AF5). Data were analysed by multiple regression analysis using SCREEN (Furnival \& Wilson, 1981). Since this program calculates the regressions of the dependent variable on all possible combinations of independent variables, it is suited for regression on non-orthogonal variables (see Table 2).

\section{Results}

A correlation matrix for all variables is given in Table 1. The number of species shows significant positive correlations with area and with the amount of wood in the vicinity (AF3 and AF5). The correlation with DS is negative. With the exception of $\mathrm{AF} 3$ the variables related to isolation are not correlated with area.

TABLE 1. Correlation matrix of the variables used. $\mathrm{S}=$ number of bird species; $\mathrm{A}=$ size of woodlot; $\mathrm{DS}=$ Distance to species pool; $\mathrm{DN}=$ Distance to nearest woodlot; $\mathrm{AF} 3=$ Area of forest within $3 \mathrm{~km}$ radius; AF5 = Area of forest within $5 \mathrm{~km}$ radius.

\begin{tabular}{|c|c|c|c|c|c|c|}
\hline $\log \mathrm{S}$ & 1.000 & & & & & \\
\hline $\log \mathrm{A}$ & $0.7543^{* *}$ & 1.000 & & & & \\
\hline $\log \mathrm{DS}$ & $-0.3998^{*}$ & -0.1904 & 1.000 & & & \\
\hline $\log \mathrm{DN}$ & -0.2903 & -0.0977 & $0.6417 * *$ & 1.000 & & \\
\hline $\log \mathrm{AF} 3$ & $0.5087 * *$ & $0.3444 *$ & $-0.6808^{* *}$ & $-0.7441 * *$ & 1.000 & \\
\hline \multirow[t]{2}{*}{$\log$ AF 5} & $0.3861 *$ & 0.2538 & $-0.7901 * *$ & $-0.5274 * *$ & $0.7606 * *$ & 1.000 \\
\hline & $\log S$ & $\log A$ & $\log \mathrm{DS}$ & $\log \mathrm{DN}$ & $\log \mathrm{AF} 3$ & $\log \mathrm{AF} 5$ \\
\hline
\end{tabular}

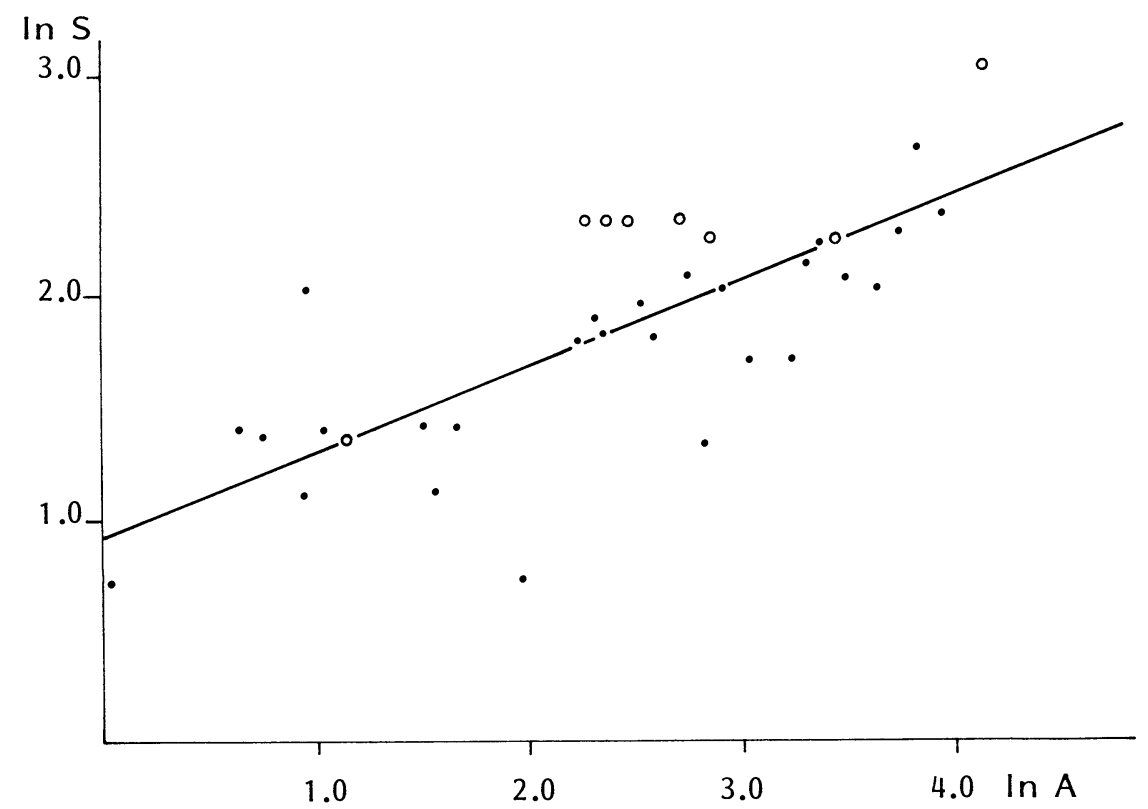

FIG. 2. Relation between the number of woodland bird species (S) and patch size (A) in forest islands in the Rhine valley. Symbols indicate two degrees of isolation (distance to species pool, DS, $0: 1-3 \mathrm{~km}$, $\bullet: \geqslant 4 \mathrm{~km}) . R^{2}=56.9$. 
Regression of $1 \mathrm{nS}$ on $1 \mathrm{nA}$ resulted in the equation $\operatorname{lnS}=0.95+0.37 \operatorname{In} \mathrm{A}$, which explains $54 \%$ of the variance. A model including AF3 as a single variable accounts for $26 \%$ of the variation only, whereas other single-factor models explain even less. The relation bet- ween species number and area is shown in Fig. 2. There is a tendency that the least isolated forest patches have somewhat more species than expected from area alone, while patches further away from the species pool have fewer species than expected. The role of isolation

TABLE 2. Regression equations describing the relationship between the number of woodland bird species (S) and variables of woodlot size and isolation. Only models with significant regression coefficients $(P<0.05)$ are given. $V^{2}=\%$ variance accounted for (adjusted $R^{2}$ ). In parentheses: standard error of coefficient. For other abbreviations see Table 1 .

\begin{tabular}{|c|c|c|}
\hline & $R^{2}$ & $V^{2}$ \\
\hline 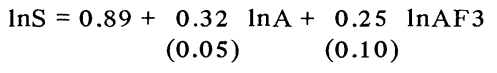 & 63.9 & 60.6 \\
\hline $\ln S=1.27+\underset{(0.05)}{0.34} \ln A-\underset{(0.06)}{0.16} \ln \ln$ & 63.7 & 60.4 \\
\hline $\ln S=1.12+\underset{(0.05)}{0.36} \ln A-\underset{(0.09)}{0.18} \ln \mathrm{DN}$ & 61.6 & 58.1 \\
\hline
\end{tabular}

TABLE 3. Frequency of occurrence of twenty-four woodland bird species in relation to distance to large forest area (DS)

\begin{tabular}{|c|c|c|c|c|c|}
\hline & \multicolumn{5}{|c|}{ Distance to large forest $(\mathrm{km})$} \\
\hline & $<2$ & $2-4$ & $5-7$ & $8-12$ & $>12$ \\
\hline Tree creeper (Certhia familiaris) & 100 & 100 & 100 & 100 & 80 \\
\hline Nuthatch (Sitta europaea) & 100 & 43 & 54 & 63 & 100 \\
\hline Golden oriole (Oriolus oriolus) & 80 & 71 & 81 & 88 & 80 \\
\hline Hobby (Falco subbuteo) & 20 & 29 & 54 & 13 & 20 \\
\hline Goldcrest (Regulus regulus) & 20 & 43 & 36 & 25 & - \\
\hline Wood warbler (Phylloscopus sibilatrix) & 20 & 57 & - & 13 & 40 \\
\hline Long-tailed tit (Aegithalos caudatus) & 100 & 86 & 81 & 100 & 60 \\
\hline Lesser spotted woodpecker (Dendrocopos minor) & 100 & 71 & 54 & 75 & 80 \\
\hline Marsh tit (Parus palustris) & 80 & 29 & 54 & 75 & 40 \\
\hline Firecrest (Regulus ignicapillus) & - & 14 & 9 & - & - \\
\hline Tawny owl (Strix aluco) & 80 & 86 & 81 & 63 & 60 \\
\hline Bullfinch (Pyrrhula pyrrhula) & 100 & 43 & 27 & 25 & 20 \\
\hline Green woodpecker (Picus viridis) & 80 & 29 & 45 & 13 & - \\
\hline Pied flycatcher (Ficedula hypoleuca) & 60 & 43 & 27 & 13 & - \\
\hline Hawfinch (Coccothraustes coccothraustes) & 60 & 29 & 9 & 13 & - \\
\hline Common buzzard (Buteo buteo) & 60 & 14 & 9 & 13 & - \\
\hline Crested tit (Parus cristatus) & 20 & 29 & 9 & - & - \\
\hline Honey buzzard (Pernis apivorus) & 20 & 29 & 9 & - & - \\
\hline Coal tit (Parus ater) & 20 & 14 & 9 & - & - \\
\hline Black woodpecker (Dryocopus martius) & 20 & 14 & 9 & - & - \\
\hline Sparrowhawk (Accipiter nisus) & 20 & 14 & - & - & - \\
\hline Raven (Corvus corax) & 20 & - & - & - & - \\
\hline Goshawk (Accipiter gentilis) & 20 & - & - & - & - \\
\hline Woodcock (Scolopax rusticola) & - & - & 9 & - & - \\
\hline Sample size & 5 & 7 & 11 & 8 & 5 \\
\hline
\end{tabular}


was analysed by adding isolation variables to the species-area equation. Table 2 gives the models in which all regression coefficients are significant at the 5\% level. The best models contain either AF3 or DS as a second variable. Adding a third variable to these models did not improve any of them significantly. The variance not accounted for might be correlated with habitat factors or sampling variation. We conclude that isolation of the forest islands has an effect on the number of bird species. The results suggest that proximity to the species pool and the amount of woodland in the vicinity of the woodlot exerts similar effects on the number of species. The effect of decreasing the degree of isolation of a particular wood on the species number can be estimated from the models in Table 2. E.g. decreasing the distance to the species pool by a factor 2 would result in an increase of species by a factor $2^{0.16}=1.12$.

Since species may differ in dispersal capacity, they should be affected by isolation to a different degree. For each species the frequency of occurrence was calculated for five categories of woods with a differing distance to large forest (Table 3). Due to the small sample the frequency values could not be corrected for area differences. Six species (tree creeper to wood warbler) show no decrease in frequency with increasing isolation, whereas in eleven species (tawny owl to sparrowhawk) there is a more or less distinct trend. Four species are intermediate. The remaining three species occurred in a single woodlot only.

The species group showing the effect of isolation includes both sedentary and migratory species as well as most of the species with large territories. The large species can only live in extensive woods or in landscape with a high density of small woods. Since the distance to the species pool and the area of wood within $3 \mathrm{~km}$ radius are correlated, the absence of large-territory species in more isolated woods may partially be due to the absence of neighbouring woodland rather than to the effect of distance.

The occurrence of goldcrest, crested tit and coal tit depends on the availability of coniferous trees. It is not known how coniferous stands are distributed over the woods, so that it remains unclear whether the distribution of these species is due to a habitat or an isolation effect.

\section{Discussion}

The number of bird species in woods is governed by internal as well as external factors. Internal factors are, for example, habitat variables and size, among external factors are features of surrounding landscape (e.g. availability of feeding sites) and geographical position in relation to other woods of the same type (Opdam, 1983). In this paper the effects of wood size and degree of isolation were demonstrated. The study plots constituted a fairly homogeneous sample of deciduous woods on small estates in a restricted geographical range. Van Dorp (1982) showed for a subsample that vegetation variables (including type of surrounding landscape) could explain the variation in $S$ only to a minor degree.

Our conclusion contradicts that of Helliwell (1976) for sixty British woods. He found no indication that overall size, woodland density in the surrounding area or distance to other woodland areas had an effect on bird species number. Therefore, he attributed the variation in $\mathrm{S}$ to differences in structural and floristical composition of the woodland. However, Helliwell analysed a heterogeneous sample and did not separate woodland species from species not restricted to woodland. Hence, effects of size and isolation have presumably been swamped by those of habitat variation.

Opdam \& Retel Helmrich (1982) found no effect of isolation on the number of bird species on Dutch heathland areas. This may be due to the fact that many birds on heathland also occur in the surrounding landscape (forest, field), so that the heathland does not function as a habitat island for those species.

In spite of the flying abilities of forest birds, which should enable them to cross a strip of non-wooded land of many hundreds of kilometres, our results suggest that even a small gap of open land may lower the immigration rate of several species of birds. The same suggestion was made by Whitcomb et al. (1981) and Willis (1974). This does not necessarily imply that forest birds never cross such a barrier; we have to assume only that 
they do not cross the non-wooded strip as often as necessary to compensate rapidly for extinction. Indeed, many bird species, even migratory ones, are notably site-tenacious and tend to settle their first breeding territory close to their native ground (Gauthreaux, 1982). Besides, a bird's visit to a remote habitat island does not always lead to a successful repopulation.

The effects of area and isolation shown here are predicted by the MacArthur-Wilson hypothesis, but we have no evidence for the existence of a dynamic species equilibrium. However, although we assume regular extinctions and repopulations, the explanation given above does not imply a species equilibrium. It would be useful to have observations from the same woods in the Rhine valley over a series of years and to analyse turnover of the species composition. At present, our data do not permit such calculations.

The consequences of fragmentation of habitat and the isolation of habitat patches for bird communities, which can be predicted from our results, are worthwhile to consider in nature conservation and landscape planning. On the basis of the equilibrium theory Diamond (1975) advocated the option that small habitat patches close to an extensive area of the same habitat type or several small patches close to each other are preferable to isolated patches. Margules, Higgs \& Rafe (1982) questioned this rule for reserve design, stating that evidence for the role of isolation in habitat patches was scarce. We consider our results to support the validity of Diamond's rule for breeding birds in mature woods.

\section{References}

Abbott, I. (1974) Numbers of plant, insect and landbird species on nineteen remote islands in the Southern Hemisphere. Biol. J. Linn. Soc. 6, 143-152.

Diamond, J.M. (1975) The island dilemma: lessons of modern biogeographic studies for the design of natural reserves. Biol. Conserv. 7, 129-146.

Fritz, R.S. (1979) Consequences of insular population structure: distribution and extinction of spruce grouse populations. Oecologia, 42, 57-65.

Furnival, G.M. \& Wilson, R.W. (1981) SCREEN: a branch and bound algorithm for subset selection. Yale School of Forestry and Environmental Studies, New Haven, Connecticut.

Gauthreaux, S.A., Jr (1982) The ecology and evolution of avian migration systems. Avian biology, Vol. VI (ed. by D. S. Farner et al.), pp. 93-168. Academic Press, New York.

Gilbert, F.S. (1980) The equilibrium theory of island biogeography: fact or fiction? J. Biogeogr. 7, 209-235.

Helliwell, D.R. (1976) The effects of size and isolation on the conservation value of wooded sites in Britain. J. Biogeogr. 3, 407-416.

Johnson, N.K. (1975) Controls of numbers of bird species on montane islands in the Great Basin. Evolution, 29, 545-574.

Lack, D. (1976) Island biology, illustrated by the land-birds of Jamaica. Studies in Ecology. III. Blackwell Scientific Publications, Oxford.

MacArthur, R.H. \& Wilson, E.O. (1967) The theory of island biogeography. Princeton University Press.

Margules, C., Higgs, A.J. \& Rafe, R.W. (1982) Modern biogeographic theory: are there any lessons for nature reserve design? Biol. Conserv. 24, 115128.

Opdam, P.F.M. (1983) De ecologie van bosvogelgemeenschappen. Vogeljaar, 31, 66-73.

Opdam, P. \& Retel Helmrich V. (1982) De vogelgemeenschappen van de Nederlandse heidevelden. RIN-rapport $82 / 4$, Leersum.

Reed, T. (1981) The number of breeding landbird species on British islands. J. Anim. Ecol. 50, 613-624.

Van Dorp, D. (1982) De avifauna van enige landgoedbossen in het rivierengebied en de relatie met de vegetatie. Internal research paper, RIN Leersum.

Vuilleumier, F. (1970) Insular biogeography in continental regions. I. The northern Andes of South America. Amer. Nat. 104, 373-388.

Whitcomb, R.F., Robbins, C.S., Lynch, J.F. et al. (1981) Effects of forest fragmentation on avifauna of the eastern deciduous forest. Forest island dynamics in man-dominated landscape (ed. by R. L. Burgess and D. M. Sharpe), pp. 125-205. Springer, New York.

Willis, E.O. (1974) Population and local extinctions of birds on Barro Colorado Island, Panama. Ecol. Monogr. 44, 153-169. 